\title{
Zakres przedmiotowy immunitetu w odniesieniu do wypowiedzi posła w trakcie konferencji prasowej ${ }^{1}$
}

\begin{abstract}
W ocenie autora opinii immunitetem materialnym objęta jest realizacja obowiązku informowania wyborców o pracy parlamentarzysty oraz o działalności organu, do którego został on wybrany. Obowiązek ten może być realizowany w drodze bezpośredniego informowania wyborców na spotkaniach z wyborcami, jak i za pośrednictwem środków masowego przekazu. Immunitetem formalnym zaś objęta jest odpowiedzialność posła za naruszenie praw osób trzecich działaniem polegającym na informowaniu wyborców o swojej pracy i działalności Sejmu. W świetle ustaleń Sądu Najwyższego przyjąć można, że pociągnięcie posła do odpowiedzialności cywilnej o naruszenie dóbr osobistych za wypowiedź na konferencji prasowej, w której relacjonuje on swoje działania mieszczące się w sferze wykonywania mandatu, wymaga uprzedniej zgody Sejmu.
\end{abstract}

Słowa kluczowe: immunitet poselski, mandat, poseł

Scope of immunity in relation to the statements made by a Deputy during a press conference: In the opinion of the author, the scope material immunity includes the fulfilment of Deputy's obligation to inform voters about the work of a parliamentarian and about the activities of the body to which he or she was elected. This obligation may be fulfilled through a direct information to voters at meetings with them as well as through the media. The scope of formal immunity is covers the Deputy's responsibility for an infringement of the rights of third parties by means of informing voters about his work and the activities of the Sejm. In the light of the Supreme Court's findings, it can be assumed that suing a Deputy to a civil court for infringement of personal rights in a statement made at a press conference in which he or she reports on his or her activities falling within the sphere of the execution of the parliamentary mandate, requires a prior consent of the Sejm.

Keywords: MP's immunity, mandate, deputy

\section{Przedmiot opinii}

Przedmiotem opinii jest odpowiedź na pytania dotyczące zakresu przedmiotowego immunitetu poselskiego w konkretnym kontekście wypowiedzi na konferencji prasowej.

1 Opinia prawna na temat zakresu przedmiotowego immunitetu w odniesieniu do wypowiedzi posła $w$ trakcie konferencji prasowej sporządzona 17 maja 2019 r. na zlecenie posła Klubu Parlamentarnego Platforma Obywatelska - Koalicja Obywatelska; BAS-WAKiU 971/19. 
Czy poseł bez uchylenia immunitetu może być pociągnięty do odpowiedzialności cywilnej (ochrona dóbr osobistych) za wypowiedzi dotyczące „wydarzeń w spółce Skarbu Państwa” wygłoszone w trakcie konferencji prasowej, którą zorganizował w ramach wykonywania mandatu? Jaki jest w tej sytuacji zakres przysługującego posłowi immunitetu materialnego i formalnego?

\section{Zakres ochrony wynikającej z immunitetu materialnego}

1. Konstytucja RP przewiduje dwa rodzaje immunitetu parlamentarnego. Immunitet formalny (art. 105 ust. 2 Konstytucji) oznacza ograniczenie dopuszczalności ścigania posła za czyny stanowiące przestępstwo lub inne czyny, których popełnienie powoduje odpowiedzialność karną w znaczeniu konstytucyjnym (wykroczenia, wykroczenia karno-skarbowe). Pociągnięcie do odpowiedzialności karnej dopuszczalne jest wyłącznie po wyrażeniu zgody przez Sejm lub przez posła, który dopuścił się czynu karalnego. Ochrona wynikająca z art. 105 ust. 2 rozciąga się wyłącznie na czyny, które nie przynależą do sfery wykonywania mandatu poselskiego.

Immunitet materialny (indemnitet) wyłącza karalność czynów popełnionych przez parlamentarzystę $\mathrm{w}$ ramach wykonywania mandatu poselskiego. Za tego rodzaju czyny poseł odpowiada wyłącznie przed Sejmem (art. 105 ust. 1 Konstytucji). Ochrona wynikająca z immunitetu materialnego nie dotyczy jednak czynów, których poseł dopuścił się w ramach działalności wchodzącej w zakres wykonywania mandatu, jeżeli naruszają one prawa osób trzecich. W takim wypadku pociągnięcie sprawcy do odpowiedzialności sądowej (karnej lub cywilnej) jest warunkowane wyrażeniem przez Sejm zgody. Działania wchodzące w zakres wykonywania mandatu, które naruszają prawa osób trzecich, podlegają ochronie niewynikającej z immunitetu materialnego, lecz ze specyficznej postaci immunitetu formalnego ${ }^{2}$. W przeciwieństwie jednak do immunitetu formalnego uregulowanego w art. 105 ust. 2 Konstytucji funkcja ochronna rozpatrywanego immunitetu obejmuje nie tylko odpowiedzialność karną, ale każdy rodzaj odpowiedzialności egzekwowanej przez sąd (a zatem również odpowiedzialność cywilną). Immunitet ten (nazywany niekiedy małym immunitetem formalnym) dotyczy również okresu po zakończeniu kadencji, a ponadto nie ma tu zastosowania instytucja wyrażenia przez samego zainteresowanego zgody na pociąg-

K. Grajewski, Komentarz do art. 6a [w:] K. Grajewski, J. Stelina, P. Uziębło, Komentarz do ustawy o wykonywaniu mandatu posta i senatora, Warszawa 2014, s. 81; E. Gierach, Komentarz do art. 105 [w:] Konstytucja RP, t. II, Komentarz. Art. 87-243, red. M. Safjan, L. Bosek, Warszawa 2016, s. 343; postanowienie SN z 2 grudnia 2009 r., sygn. akt I CSK 140/09, OSNC 2010, nr 5, poz. 83; postanowienie TK 26 listopada 2015 r., sygn. akt SK 8/13. 
nięcie do odpowiedzialności. Obydwa immunitety uregulowane w art. 105 ust. 1 Konstytucji (immunitet materialny oraz specyficzna forma immunitetu formalnego) przysługują posłowi jedynie wówczas, gdy jego działalność wpisuje się w sprawowanie mandatu. Teza ta jednoznacznie wynika ze zdania pierwszego zawartego w omawianym przepisie. W tych przypadkach, gdy czyn popełniony przez posła nie mieści się w zakresie wykonywania mandatu i nie narusza norm prawa karnego, wówczas sprawca ponosi odpowiedzialność sądową na zasadach ogólnych (w procesie cywilnym). Gdy czyn popełniony poza sferą wykonywania mandatu narusza ustawę karną, poseł podlega ochronie wynikającej z immunitetu formalnego, o którym mowa w art. 105 ust. 2 Konstytucji.

W piśmiennictwie istnieje konsensus co do tego, że immunitety parlamentarne - będące przywilejem deputowanego - stanowią odstępstwo od konstytucyjnej zasady równości wobec prawa (art. 32 ust. 1) oraz od zasady państwa prawnego (art. 2) nakazującej ustanowienie adekwatnych środków, zapewniających, by prawo było przestrzegane ${ }^{3}$. Jak wskazuje L. Garlicki: przepisów o immunitecie nie można tym samym poddawać wykładni rozszerzającej (tak też Sąd Najwyższy w odniesieniu do immunitetu poselskiego - w uchwale z 16 lutego 1994, I KZP 40/93, OSNKW 1994, nr 3-4, s. 19-20, a w odniesieniu do immunitetu adwokackiego, co tė̇ ma jednak walor ogólniejszy - w uchwale z 24 lutego 1998, I KZP 36/97, OSNKW 1998, nr 3-4, s. 9-10). Oznacza to m.in., że nie można domniemywać istnienia immunitetu tam, gdzie nie został on wyraźnie ustanowiony przez prawo pozytywne.

2. Katalog czynności, które mieszczą się w konstytucyjnym pojęciu „działalności wchodzącej w zakres sprawowania mandatu”, tworzy zbiór czynności związanych z wykonywaniem praw i obowiązków członka parlamentu, wynikających z pełnienia tej funkcji. W obecnym stanie prawnym ustawą, która konkretyzuje pojęcie „sprawowania mandatu”, jest ustawa z 9 maja 1996 r. wykonywaniu mandatu posła i senatora (Dz.U. 2016, poz. 1510, ze zm.; dalej: u.w.m.p.s.). Zgodnie $\mathrm{z}$ art. 6 ust. 2 u.w.m.p.s. działalność wchodząca w zakres sprawowania mandatu obejmuje: zgłaszanie wniosków, wystąpienia lub głosowania na posiedzeniach Sejmu, Senatu lub Zgromadzenia Narodowego oraz ich organów, na posiedzeniach klubów, kół $i$ zespołów poselskich, senackich lub parlamentarnych, a także inna działalność związana nieodłacznie ze sprawowaniem mandatu.

Analiza ustawy o wykonywaniu mandatu posła i senatora pozwoliła doktrynie $^{5}$ na wyodrębnienie dwóch grup czynności, które mieszczą się w zakresie omawianego pojęcia konstytucyjnego. Pierwsza obejmuje czynności podejmowane przez posła lub senatora na forum odpowiednio Sejmu, Senatu, Zgromadzenia Narodowego oraz ich organów, które polegać mogą na wykonywaniu uprawnień

3 L. Garlicki, Uwaga 6 do art. 105 [w:] Konstytucja Rzeczypospolitej Polskiej. Komentarz, t. II, red. L. Garlicki, Warszawa 2000, oraz cytowana tam literatura.

4 Ibidem.

5 K. Grajewski, Immunitet parlamentarny w prawie polskim, Warszawa 2001, s. 116. 
przewidzianych w art. 14 i 15 u.w.m.p.s., czyli: wyrażaniu swojego stanowiska oraz zgłaszaniu wniosków w sprawach rozpatrywanych na posiedzeniach Sejmu, Senatu i ich organów; wybieraniu i byciu wybieranym do organów Sejmu i Senatu; zwracaniu się do prezydiów o rozpatrzenie określonej sprawy przez izby lub ich komisje; zwracaniu się do komisji o rozpatrzenie określonej sprawy; uczestnictwie w podejmowaniu inicjatyw ustawodawczych i uchwałodawczych oraz w rozpatrywaniu projektów ustaw i uchwał; uczestnictwie w dyskusji nad sprawami rozpatrywanymi przez izby i ich komisje. Omawiana grupa uprawnień obejmuje również - w przypadku posłów - prawo wnoszenia interpelacji i zapytań poselskich. Trzeba podkreślić, że zakres czynności podejmowanych przez parlamentarzystów w ramach działalności w izbach nie został w przywołanych przepisach ujęty w sposób wyczerpujący. Świadczy o tym treść zdań wstępnych z art. 14 i 15 u.w.m.p.s., która jednoznacznie wskazuje, że wyliczenie „praw” przysługujących parlamentarzystom „w wykonywaniu mandatu” nie ma charakteru zamkniętej enumeracji.

Drugą grupę działań przynależnych do sfery wykonywania mandatu tworzą czynności wykonywane jako „działalność w terenie”6. Zbiór ten obejmuje aktywność podejmowaną w ramach: uzyskiwania informacji i materiałów, wstępu do pomieszczeń, w których znajdują się te informacje i materiały, oraz wglądu w działalność organów administracji rządowej i samorządu terytorialnego, a także spółek z udziałem Skarbu Państwa oraz zakładów i przedsiębiorstw państwowych i samorządowych (tzw. prawo do informacji - art. 19 ust. 1 u.w.m.p.s.); wykonywania interwencji w organie administracji rządowej i samorządu terytorialnego, zakładzie lub przedsiębiorstwie państwowym oraz organizacji społecznej, a także w jednostkach gospodarki niepaństwowej dla załatwienia wnoszonej przez parlamentarzystę sprawy oraz zaznajamiania się z tokiem jej rozpatrywania (tzw. prawo do interwencji - art. 20 u.w.m.p.s.); uczestnictwa w sesjach sejmików województw, rad powiatów i rad gmin, właściwych dla okręgu wyborczego, z którego parlamentarzysta został wybrany, lub właściwych ze względu na siedzibę biura posła (art. 22 u.w.m.p.s.); pracy w biurach poselskich i senatorskich utworzonych dla obsługi działalności w terenie (art. 23 u.w.m.p.s.), informowania wyborców o swojej działalności oraz o działalności organu, do którego parlamentarzysta został wybrany (art. 1 ust. 2 u.w.m.p.s.).

W innym ujęciu wskazuje się, że „sprawowanie mandatu”, obok kategorii wyżej wymienionych, obejmuje także działalność w organach, gremiach i ciałach (krajowych lub międzynarodowych), w których posłowie lub senatorowie zasiadają jako reprezentanci izb parlamentu ${ }^{7}$, jak również działalność podejmowa-

$6 \quad$ Wyrażenie ustawowe $\mathrm{z}$ art. 23 ust. 1 opisujące wykonywanie praw określonych w rozdziale 4 u.w.m.p.s.

7 L. Garlicki, Uwaga 13 do art. 105 [w:] Konstytucja Rzeczypospolitej Polskiej. Komentarz, t. II, red. L. Garlicki, Warszawa 2000. Pogląd ten zyskał aprobatę Trybunału Konstytucyjnego, zob. wyrok z 21 kwietnia 2016 r., sygn. akt K 2/14. 
ną na zewnątrz parlamentu w imieniu jego izb lub ich organów. Kategoria ta obejmuje rozmaite rozwiązania instytucjonalne (członkostwo w Radzie Ochrony Pracy $^{8}$, członkostwo w grupach parlamentarnych działających w ramach współpracy międzyparlamentarnej, członkostwo w Zgromadzeniu Parlamentarnym Rady Europy, członkostwo w Zgromadzeniu Parlamentarnym NATO, reprezentację Sejmu w postępowaniu przez Trybunałem Konstytucyjnym, status oskarżyciela w postępowaniu przed Trybunałem Stanu' ${ }^{9}$, reprezentację komisji śledczej i Komisji Odpowiedzialności Konstytucyjnej wykonywaną przez przewodniczących tych komisji). Immunitet materialny - w omawianym przypadku - będzie znajdował zastosowanie wyłącznie do takich funkcji i stanowisk, które wiążą się z reprezentowaniem Sejmu (Senatu) lub ich organów. Zakres ochrony wynikającej z immunitetu materialnego nie obejmie zatem działań podejmowanych przez parlamentarzystę w ramach pełnienia innych funkcji publicznych, które nie wiążą się z reprezentacją macierzystej izby oraz nie pozostają w związku z funkcjami Sejmu i Senatu. Na przykład czynności posła, pełniącego funkcję ministra, wykonywane jako obowiązki urzędowe związane $\mathrm{z}$ tą funkcją, nie korzystają z ochrony wynikającej z art. 105 ust. 1 Konstytucji ${ }^{10}$. Podobnie zakres omawianego przywileju nie obejmuje działań wynikających z wykonywania obowiązków związanych z funkcją członka organu kolegialnego, którego działalność nie wiąże się z funkcjami Sejmu, zaś członkostwo nie jest związane z reprezentowaniem Sejmu. Przykładem może być status członka Rady Służby Cywilnej, Krajowej Rady Sądownictwa czy Krajowej Rady Prokuratorów ${ }^{11}$. We wszystkich wymienionych przypadkach obowiązki związane z wykonywaniem powierzonej przez parlament funkcji mają charakter niezależny względem zadań mandatowych. Jakkolwiek funkcje te związane są z wykonywaniem mandatu posła lub senatora, to jednak ich sprawowanie nie jest chronione immunitetem materialnym.

W orzecznictwie Sądu Najwyższego ${ }^{12}$ i Trybunału Konstytucyjnego ${ }^{13}$ - przy aprobacie doktryny ${ }^{14}$ - podkreśla się również, że mandat musi: [być] wykonywany przy użyciu godziwych metod postepowania, nie naruszajacych zasad dobrej wiary ze strony społeczeństwa do tego, kto go posiada. Nie może on być więc

8 P. Sarnecki, Immunitet posłów i senatorów w radach pozaparlamentarnych, „Przegląd Sejmowy" 2015, nr 6, s. 28.

9 K. Grajewski, Komentarz do art. 6 [w:] K. Grajewski, J. Stelina, P. Uziębło, Komentarz do ustawy o wykonywaniu mandatu posła i senatora, Warszawa 2014, s. 75.

10 K. Grajewski, Immunitet, op. cit., s. 94; K. Kubuj, W sprawie zakresu obowiązywania immunitetu materialnego przysługującego posłowi Bartoszowi Arłukowiczowi w kontekście jego wystąienia podczas rozpatrywania wotum nieufności wobec niego jako urzędującego ministra, „Przegląd Sejmowy” 2014, nr 5, s. 114.

11 P. Sarnecki, Immunitet posłów, op. cit., s. 28.

12 Wyrok SN z 13 kwietnia 2007 r., sygn. akt I CSK 31/07, Biuletyn SN 2007, nr 7, poz. 11.

13 Wyrok TK z 21 kwietnia 2016 r., sygn. akt K 2/14.

14 K. Grajewski, Immunitet, op. cit., s. 118; L. Garlicki, Uwaga 14 do art. 105, op. cit. 
wykonywany za pomoca rozmaitych nieuczciwych machinacji, takich np., jak postugiwanie się fałszywymi dokumentami lub fałszowanie wykorzystywanych dokumentów $w$ swej działalności poselskiej, nie może wyrażać się w podburzaniu do dokonywania aktów przemocy lub braniu w nich udziału, albo w publicznym nawoływaniu do nieposłuszeństwa obowiązującej ustawie itp. ${ }^{15}$.

3. Zagadnienie będące przedmiotem kontrowersji dotyczy kwestii, czy wypowiedzi posła w trakcie konferencji prasowej mogą być zaklasyfikowane jako działania podlegające ochronie wynikającej z immunitetu materialnego. W takim wypadku pociągnięcie posła do odpowiedzialności cywilnej z tytułu naruszenia dóbr osobistych wypowiedziami wygłoszonymi na konferencji prasowej wymagałoby - zgodnie z art. 105 ust. 1 zdanie drugie Konstytucji - uprzedniego wyrażenia zgody przez Sejm. Stanowisko przeciwne, czyli supozycja, że wypowiedzi posła na konferencji prasowej pozostają poza sferą wykonywania mandatu, prowadziłoby do wniosku, że proces cywilny za naruszenie dóbr osobistych mógłby się toczyć na zasadach ogólnych, tj. bez zgody Sejmu na pociągnięcie do odpowiedzialności sądowej.

Analiza orzecznictwa Sądu Najwyższego pozwala stwierdzić, że wykonywanie mandatu może przyjmować wskazaną wyżej formę (konferencja prasowa) wówczas, gdy służy one realizacji obowiązku informowania wyborców o pracy parlamentarzysty oraz o działalności organu, do którego został on wybrany (art. 1 ust. 2 u.w.m.p.s.). W uzasadnieniu wyroku z 29 października 2010 r., sygn. akt I CSK 651/09 (OSNC 2011, nr 6, poz. 74), Sąd Najwyższy stwierdził, że: obowiazek ten może być realizowany $w$ drodze bezpośredniego informowania wyborców lub ich przedstawicieli indywidualnie lub grupowo (na spotkaniach $z$ wyborcami), jak $i$ za pośrednictwem środków masowego przekazu, przez zamieszczanie informacji $w$ prasie lub ogłaszanie ich przez radio lub telewizje, udzielanie odpowiedzi na pytania dziennikarzy $i$ wywiady udzielane dziennikarzom. Immunitetem [wynikającym z art. 105 ust. 1 zdanie drugie - dopisek W.O.-S.] objęta jest [...] odpowiedzialność posła za naruszenie praw osób trzecich działaniem polegajacym na informowaniu wyborców o swojej pracy i działalności Sejmu. Chodzi o informowanie przez posła o swojej pracy jako posła, a nie o jakiejkolwiek innej pracy wykonywanej poza parlamentem i niezwiązanej ze sprawowaniem mandatu. $\mathrm{Na}$ przykład, informacja może dotyczyć wystąień posła na posiedzeniach Sejmu i jego organów, składanych przez niego wnioskach, interpelacjach oraz zapytaniach poselskich i obejmować ich treść. Chodzi także o informowanie o działalności Sejmu jako organu władzy ustawodawczej oraz o działalności organów Sejmu. Immunitetem objęta jest zatem odpowiedzialność posła za udzielanie informacji m.in. o uchwalonych ustawach, uchwałach i innych dokumentach będacych wynikiem pracy Sejmu lub jego organów, jak i o przebiegu pracy nad nimi, nie wyłączając informacji o treści dokumentów, które były podstawa tej pracy oraz stanowiska

15 Uchwała SN z 16 lutego 1994 r., sygn. akt I KZP 40/93, OSNKW 1994, nr 3-4, poz. 18. 
innych posłów wyrażonego w jej toku. Nie jest natomiast objęta immunitetem odpowiedzialność posła za naruszenie dóbr osobistych polegajace na przedstawieniu nieprawdziwych faktów dotyczacych osób, które znalazły się w kręgu zainteresowania posła ze względu na działalność wchodzacą w zakres sprawowanego mandatu, jeżeli fakty te nie zostały wskazane $w$ toku prac Sejmu ( $w$ tym $w$ dokumentach stanowiacych podstawę lub wynik tych prac). Nie jest również objęta immunitetem odpowiedzialność posła za naruszenie dóbr osobistych innych osób wypowiedziami obejmujacymi oceny $i$ opinie o tych osobach, chyba że stanowity one element dokumentu będącego podstawa lub wynikiem prac Sejmu (jego organów) albo wniosku, wystapienia lub głosowania. Jeżeli poseł powołuje się na immunitet, to na nim spoczywa ciężar dowodu istnienia okoliczności uzasadniających zastosowanie immunitetu, powinien więc wykazać, że działalność, za która pociagnięty jest do odpowiedzialności, wchodzi $w$ zakres sprawowania mandatu. Jeżeli pociagnięty zostaje do odpowiedzialności ze względu na treść wypowiedzi udzielonej dziennikarzowi, powinien udowodnić, że wypowiedź stanowiła informację o jego pracy jako posła lub o działalności Sejmu lub jego organów ${ }^{16}$.

\section{Podsumowanie}

Zakres ochrony wynikającej z poselskiego immunitetu materialnego obejmuje: (1) wykonywanie praw i obowiązków na forum Sejmu i jego organów oraz klubów, kół i zespołów poselskich, (2) wykonywanie praw i obowiązków związanych z działalnością terenową, oraz (3) czynności wykonywane na zewnętrz parlamentu służące realizacji jego funkcji oraz wiążące się z reprezentacją parlamentu lub jego organów.

Immunitetem materialnym objęta jest realizacja obowiązku informowania wyborców o pracy parlamentarzysty oraz o działalności organu, do którego został on wybrany (art. 1 ust. 2 u.w.m.p.s.). Obowiązek ten może być realizowany w drodze bezpośredniego informowania wyborców lub ich przedstawicieli indywidualnie lub grupowo (na spotkaniach z wyborcami), jak i za pośrednictwem środków masowego przekazu (konferencje prasowe), udzielanie odpowiedzi na pytania dziennikarzy i wywiady udzielane dziennikarzom, a także przez aktywność w mediach społecznościowych.

16 Podobnie w wyroku z 21 września 2011 r., sygn. akt I CSK 754/10, Sąd Najwyższy uznał, że: immunitetem parlamentarnym objęta jest działalność (wypowiedzi) posła, nie tylko na forum parlamentu i jego organów oraz klubów, kół i zespołów poselskich, lecz również wszelka inna działalność, $w$ tym wypowiedzi publiczne także w prasie radiu i telewizji, jeżeli sq zwiqzane nieodłacznie ze sprawowaniem mandatu; por. wyrok SN z 13 kwietnia 2007 r., sygn. akt I CSK 31/07. 
Immunitetem wynikającym z art. 105 ust. 1 zdanie drugie Konstytucji (specyficzna postać immunitetu formalnego) objęta jest odpowiedzialność posła za naruszenie praw osób trzecich działaniem polegającym na informowaniu wyborców o swojej pracy i działalności Sejmu. Zachowania posła, chronione immunitetem materialnym i formalnym z art. 105 ust. 1 zdanie drugie Konstytucji, muszą bezpośrednio i wprost wynikać z funkcji parlamentarzysty, a jego związek ze sprawowaniem mandatu nie może budzić wątpliwości. O tym, czy w sprawie, na kanwie której sformułowane zostały pytania przedstawione na początku opinii, wypowiedzi posła podlegają ochronie wynikającej z immunitetu, o którym mowa w art. 105 ust. 1 zdanie drugie Konstytucji, rozstrzyga związek między treścią tych wypowiedzi a sferą wykonywania mandatu parlamentarnego. W świetle ustaleń Sądu Najwyższego przyjąć można, że pociągnięcie posła do odpowiedzialności cywilnej o naruszenie dóbr osobistych za wypowiedź na konferencji prasowej, w której relacjonuje on swoje działania mieszczące się w sferze wykonywania mandatu, a zarazem treść tych informacji nie polega na: przedstawieniu nieprawdziwych faktów dotyczących osób, które znalazły się w kręgu zainteresowania posła ze względu na działalność wchodząca w zakres sprawowanego mandatu, wymaga uprzedniej zgody Sejmu. Odniesienie tej zasady do konkretnego stanu faktycznego pozostaje poza zakresem opinii.

\section{Bibliografia}

Garlicki L., Uwaga 6 i 13 do art. 105 [w:] Konstytucja Rzeczypospolitej Polskiej. Komentarz, t. II, red. L. Garlicki, Warszawa 2000.

Gierach E., Komentarz do art. 105 [w:] Konstytucja RP, t. II, Komentarz. Art. 87-243, red. M. Safjan, L. Bosek, Warszawa 2016.

Grajewski K., Immunitet parlamentarny w prawie polskim, Warszawa 2001.

Grajewski K., Komentarz do art. 6 i art. 6a [w:] K. Grajewski, J. Stelina, P. Uziębło, Komentarz do ustawy o wykonywaniu mandatu posła i senatora, Warszawa 2014.

Kubuj K., W sprawie zakresu obowiązywania immunitetu materialnego przystugującego posłowi Bartoszowi Arłukowiczowi w kontekście jego wystąienia podczas rozpatrywania wotum nieufności wobec niego jako urzędującego ministra, „Przegląd Sejmowy” 2014, nr 5.

Sarnecki P., Immunitet posłów i senatorów w radach pozaparlamentarnych, „Przegląd Sejmowy" 2015, nr 6. 